\title{
Ketrampilan Komunikasi Interpersonal, Penguasaan Teori Praktik Fisioterapi, dan Kompetensi Profesi Fisioterapis Mahasiswa yang Belajar Praktik Pengalaman Klinis di Rumah Sakit Ortopedi Prof. R. Soeharso Surakarta
}

\author{
Sumartinah \\ Fakultas Theologia, Universitas Kristen Surakarta, Jawa Tengah, Indonesia \\ sumartinah@gmail.com
}

\begin{abstract}
The research is aimed at describing the interpersonal communication skills, the mastery of physiotherapy theory and practice, and the competence of physiotherapist profession of the students of the physiotherapy students conducting clinical practice at the Orthopedics Hospital Prof. Dr. R. Soeharso Surakarta. The research used a qualitative-etnomethodology by describing the process of the students' clinical practice. Subject of the research were 82 Physiotherapy students who conducted clinical practice at the Orthopedics Hospital Prof. Dr. R. Soeharso Surakarta. Data of the research were taken by collecting the clinical status records made by the students, and the use of the documents. The results of the research shows that (1) The interpersonal communication skills of the students of Diploma 3 in Physiotherapy range from Poor, Fair, Fairly Good, to Good (dominated by Fairly Good, and Good categories). Meanwhile, the interpersonal communication skills of the students of Diploma 4 in Physiotherapy range from Poor, Fair, Fairly Good, to Good (dominated by Poor and Good categories). (2) The mastery of physiotherapy theory and practice of the students of Diploma 3 in Physiotherapy range from Fair, Fairly Good, to Good (dominated by Good categories). Meanwhile, the mastery of physiotherapy theory and practice of the students of Diploma 4 in Physiotherapy range from Fair, Fairly Good, Good, to Very Good (dominated by Fairly Good categories). (3) The Competence of Physiotherapist Profession the students of Diploma 3 in Physiotherapy range from Fair, Fairly Good, Good, to Very Good (dominated by Fairly Good, and Good categories). Meanwhile, the Competence of Physiotherapist Profession the students of Diploma 4 in Physiotherapy range from Fair, Fairly Good, Good, to Very Good (dominated by Fair categories).
\end{abstract}

Keywords: communication skills; competence of physiotherapist profession; the mastery of physiotherapy theory and practice

\begin{abstract}
Abstrak: Penelitian ini bertujuan untuk mendeskripsikan keterampilan komunikasi interpersonal, penguasaan teori dan praktik fisioterapi, dan kompetensi profesi fisioterapis mahasiswa mahasiswa fisioterapi yang melakukan praktik klinis di Rumah Sakit Ortopedi Prof. Dr. R. Soeharso Surakarta. Penelitian ini menggunakan kualitatif-etnometodologi dengan menggambarkan proses praktik klinis siswa. Subjek penelitian adalah 82 mahasiswa Fisioterapi yang melakukan praktik klinis di Rumah Sakit Ortopedi Prof. Dr. R. Soeharso Surakarta. Data penelitian diambil dengan mengumpulkan catatan status klinis yang dibuat oleh siswa, dan penggunaan dokumen. Hasil penelitian menunjukkan bahwa (1) Keterampilan komunikasi interpersonal dari siswa Diploma 3 dalam Fisioterapi berkisar dari kategori Buruk, Adil, Cukup Baik, hingga Baik (didominasi oleh kategori Cukup Baik, dan Baik). Sementara itu, keterampilan komunikasi interpersonal siswa Diploma 4 dalam Fisioterapi berkisar dari Buruk, Adil, Cukup Baik, hingga Baik (didominasi oleh kategori Buruk dan Baik). (2) Penguasaan teori fisioterapi dan praktik mahasiswa Diploma 3 dalam Fisioterapi berkisar dari Adil, Cukup Baik, hingga Baik (didominasi oleh kategori Baik).
\end{abstract}


Sementara itu, penguasaan teori fisioterapi dan praktik para mahasiswa Diploma 4 dalam Fisioterapi berkisar dari Adil, Cukup Baik, Baik, hingga Sangat Baik (didominasi oleh kategori Cukup Baik). (3) Kompetensi Profesi Fisioterapis mahasiswa Diploma 3 dalam Fisioterapi berkisar dari Cukup, Cukup Baik, Bagus, hingga Sangat Bagus (didominasi oleh kategori Cukup Bagus, dan Baik). Sementara itu, Kompetensi Profesi Fisioterapis mahasiswa Diploma 4 dalam Fisioterapi berkisar dari Wajar, Cukup Baik, Bagus, hingga Sangat Bagus (didominasi oleh kategori Wajar).

Kata kunci: keterampilan komunikasi interpersonal; kompetensi profesi fisioterapis; penguasaan teori; praktik fisioterapi

\section{PENDAHULUAN}

Pendidikan tenaga kesehatan sebagai bagian integral dari pembangunan kesehatan nasional merupakan salah satu elemen penting dalam mewujudkan Indonesia Sehat 2010. Menurut Dep. Kes. RI (2001: 1) pendidikan fisioterapi, merupakan institusi yang menghasilkan tenaga fisioterapis yang profesional bertujuan mendidik mahasiswa melalui proses belajar mengajar (PBM) sehingga memiliki pengetahuan, ketrampilan, nilai dan sikap yang diperlukan bagi profesinya. Dalam rangka mencapai tujuan pendidikan tersebut diperlukan berbagai bentuk pengalaman belajar di antaranya belajar klinis (PBK) yang merupakan pengalaman belajar praktek yang diperoleh di unit-unit pelayanan fisioterapi rumah sakit di bawah bimbingan instruktur. Program belajar klinik merupakan bagian intrakulikuler yang dilaksanakan oleh mahasiswa semester akhir yang mencakup penerapan teori yang diperoleh selama periode perkuliahan ke dalam situasi nyata di lapangan secara terbimbing dan terpadu sebagai upaya dalam membentuk fisioterapis yang profesional.

Rumah Sakit Ortopedi Prof. Dr. R. Soeharso Surakarta (RSO. 2001:1) merupakan Rumah Sakit Rujukan Nasional Ortopedi, Traumatologi dan Rehabilitasi Medik yang memberikan pelayanan kesehatan paripurna, yaitu pelayanan menyeluruh yang meliputi pelayanan promotif, preventif, kuratif dan rehabilitatif semua kasus serta kecacatan dengan melakukan temuan tindakan dari yang sederhana sampai subspesialistis dan tindakan rehabilitasi medik ortopedi melalui pendekatan fisioterapi, ortotik, prostetik, okupasi terapi, psikologi serta pekerja sosial medik menuju rehabilitasi sosial dan rehabilitasi kerja.

Selain itu Rumah Sakit Ortopedi juga digunakan sebagai tempat pendidikan praktek dan pelatihan ortopedi tingkat nasional untuk tenaga medis dan paramedis. Seperti halnya telah dilakukan bersama beberapa universitas dan lembaga dari dalam maupun dari luar negeri bekerjasama untuk belajar di bidang medis atau paramedis bagi mahasiswa maupun pakar kesehatan. Termasuk di sini ada beberapa institusi pendidikan fisioterapi di Indonesia yang telah bekerja sama dengan Rumah Sakit Ortopedi menjadi tempat belajar praktek pengalaman klinis bagi mahasiswa dalam rangka memenuhi tujuan pendidikan yang ingin dicapai oleh institusi tersebut. Penelitian ini dilakukan dengan tujuan untuk memperoleh bukti empiris tentang bagaimana ketrampilan komunikasi interpersonal, penguasaan teori praktek fisioterapi dan kompetensi profesi fisioterapis para mahasiswa yang belajar praktek pengalaman klinis di Rumah Sakit Ortopedi. 


\section{Hubungan Interpersonal}

Jalaluddin Rakhmat (2001:119-129) menyatakan bahwa komunikasi yang efektif ditandai dengan hubungan interpersonal yang baik. Komunikasi yang efektif meliputi banyak unsur, tetapi hubungan interpersonal dianggap yang paling penting. Setiap kali melakukan komunikasi orang bukan saja hanya sekedar menyampaikan isi pesan atau "content" tetapi juga menentukan kadar hubungan interpersonal atau "relationship".

\section{Memahami Ketrampilan Dasar Berkomunikasi Interpersonal}

Supratiknya (1995:10) menyatakan bahwa agar mampu memulai, mengembangkan dan memelihara komunikasi yang akrab, hangat dan produktif dengan orang lain diperlukan sejumlah ketrampilan dasar berkomunikasi sebagai berikut:

Pertama, komunikator harus mampu memahami beberapa hal secara rinci mencakup sikap percaya, pembukaan diri dan penerimaan diri. Kedua, komunikator harus mampu mengkomunikasikan pikiran dan perasaan secara tepat dan jelas. Ketiga, komunikator harus mampu menerima dan memberi dukungan yang menolong. Keempat, komunikator harus mampu memecahkan konflik dan bentuk-bentuk masalah interpersonal lain yang muncul dalam komunikasi dengan orang lain melalui cara-cara yang konstruktif.

\section{Faktor-faktor yang Menumbuhkan Hubungan Interpersonal}

Menurut Jalaluddin Rakhmat (2001: 129), ada tiga hal yang mendukung faktor-faktor dalam menumbuhkan hubungan interpersonal yaitu sikap percaya, sikap suportif dan sikap terbuka. Sikap "percaya" didefinisikan sebagai mengandalkan perilaku orang untuk mencapai tujuan yang dikehendaki, yang pencapaiannya tidak pasti dan dalam situasi yang penuh resiko. Tiga unsur pokok percaya : ada situasi yang menimbulkan resiko, menyadari bahwa akibat-akibatnya tergantung pada perilaku orang lain dan perilaku orang lain berakibat baik bagi orang yang mempercayainya. Keuntungan yang bisa diambil dari sikap "percaya" adalah meningkatkan komunikasi interpersonal karena membuka saluran komunikasi, memperjelas pengiriman dan penerimaan informasi, serta memperluas peluang komunikasi untuk mencapai maksud.

Jack R Gibb dalam Jalaluddin Rakhmat (2001: 134) menjelaskan bahwa sikap sportif, merupakan sikap yang mengurangi sikap defensif/mempertahankan diri (tidak menerima, tidak jujur dan tidak empatis). Sikap terbuka (open-mindedness) amat besar pengaruhnya dalam menumbuhkan komunikasi interpersonal yang efektif. Adapun karakteristik orang yang bersikap terbuka antara lain:

a. Menilai peran secara obyektif, dengan menggunakan data.

b. Melihat dengan mudah, melihat nuansa.

c. Berorientasi pada isi.

d. Mencari informasi dari berbagai sumber.

e. Lebih bersifat profesional dan bersedia mengubah kepercayaannya.

f. Mencari pengertian pesan yang tidak sesuai dengan kepercayaannya. 


\section{Penguasaan Teori-Praktek Fisioterapi}

Menurut Menteri Kesehatan Republik Indonesia (2001:1), fisioterapi adalah pelayanan kesehatan yang ditujukan kepada individu atau kelompok untuk mengembangkan, memelihara, memulihkan gerak dan fungsi tubuh sepanjang daur kehidupan dengan menggunakan penanganan secara manual, peningkatan gerak, peningkatan gerakan dengan peralatan fisik; elektroterapeutik dan mekanis, pelatihan fungsi serta komunikasi. Menurut Word Confederation Physiotherapy / WCPT (terjemahan 1995: 22), fisioterapi adalah profesi yang mempunyai otonomi sendiri serta mandiri, yang melaksanakan praktek secara terbuka dan mempunyai hubungan sejajar dengan profesi medis dan tenaga profesional lainnya. Fisioterapi memberikan pelayanan pada sektor privat dan umum di rumah sakit, pusat rehabilitasi, puskesmas, klinik, sekolah dan tempat kerja yang lain.

Menurut WCPT (1999), fisioterapi adalah pelayanan yang diberikan kepada masyarakat untuk meningkatkan, memelihara dan memulihkan kemampuan maksimum gerak dan fungsi dari seluruh perjalanan hidup seseorang dari ancaman penyakit, cedera dan proses usia. Kepenuhan gerak fungsional adalah arti kesehatan, fisioterapi melibatkan interaksi terapis, pasien/klien, keluarga, kelompok dalam proses dari pemeriksaan potensi gerak, menetapkan tujuan dan sasaran, dengan menggunakan ilmu pengetahuan dan ketrampilan yang unik bagi fisioterapis.

Fisioterapi sebagai ilmu memiliki batang tubuh pengetahuan teoritik (body of knowledge) yang jelas dan adanya institusi pendidikan. Menurut WCPT (1995:2), jati diri keilmuan fisioterapi berpedoman pada filsafat ilmu, sehingga dapat memenuhi karakteristik atau spesifikasi pengetahuan yang berdimensi ilmiah. Karakteristik dan spesifikasi ilmu fisioterapi meliputi ; ontologi ilmu fisioterapi yang dijabarkan dalam obyek materi dan obyek forma fisioterapi, epistemologi yang dijabarkan dalam asumsi dan prinsip fisioterapi serta axiologi yang dijabarkan sebagai postulat fisioterapi.

Adapun beberapa sumber fisis yang digunakan sebagai dasar sarana pencegahan dan pengobatan gangguan gerak fungsional tubuh atau akibat penyakit antara lain adalah terapi arus listrik frekwensi rendah dan menengah, terapi arus listrik frekwensi tinggi, sinar infra merah, sinar ultra violet, sinar laser, gelombang suara, air atau zat cair, dan gerakan. Ikatan Fisioterapi Indonesia (2002) berpendapat bahwa lingkup pelayanan fisioterapi diterapkan pada dimensi promotif, preventif, kuratif dan rehabilitatif dengan cakupan sepanjang rentang kehidupan manusia sejak praseminasi sampai ajal. Adapun hal-hal yang perlu dipahami dan dikuasai sebelum melaksanakan terapi kepada pasien / klien adalah pengetahuan dasar teori praktek sebagai berikut assessment fisioterapi, diagnosa fisioterapi, perencanaan terapi, tindakan/ intervensi fisioterapi, evaluasi dan ee-evaluasi.

\section{Kompetensi Profesi Fisioterapis}

Menurut Ikatan Fisioterapi Indonesia (2001), kompetensi fisioterapis merupakan uraian dan penjabaran dari komponen-komponen fungsi fisioterapi antara lain:

a. Menggunakan ketrampilan manajemen dalam pelayanan fisioterapi.

b. Menunjukkan sikap profesional sebagai seorang fisioterapis. 
c. Berperan serta dalam merumuskan dan menetapkan kebijakan perencanaan program dan melaksanakan upaya pelayanan kesehatan sebagai tim terpadu sesuai dengan sistem pelayanan kesehatan.

d. Merencanakan intervensi/tindakan fisioterapi sesuai dengan diagnosa fisioterapi, problematik dan kebutuhan pasien.

e. Melakukan intervensi fisioterapi.

f. Melakukan evaluasi proses fisioterapi.

Dalam jurnal fisioterapi (1990:5-13), Ikatan Fisioterapi Indonesia menyatakan bahwa fisioterapis merupakan tenaga fisioterapi yang dalam melakukan tugasnya harus berorientasi pada kualitas dan efisiensi dengan berlandaskan pada kompetensi profesionalnya.

Adapun ciri-ciri fisioterapis profesional adalah:

a. Mempunyai ilmu pengetahuan dasar yang kuat dalam berbagai ilmu pengetahuan alam, ilmu perilaku, ilmu kedokteran dan kesehatan, ilmu sosial dan masyarakat dalam waktu tertentu.

b. Dalam melaksanakan kegiatan harus berdasarkan pada standar yang telah ditentukan oleh profesi sesuai dengan nilai-nilai yang ada di masyarakat.

c. Setiap tindakan ditujukan untuk pemenuhan kebutuhan masyarakat dan bukan untuk kepentingan pribadi semata.

d. Setiap kegiatan dilakukan dengan menggunakan pendekatan ilmiah dan memiliki kemampuan yang tercermin dalam pengambilan keputusan dalam melakukan setiap tindakan.

e. Mengembangkan diri terus menerus dan selalu menambah pengetahuan dan ketrampilan guna kepentingan umum dan masyarakat.

f. Menyadari adanya komponen identitas atau ciri-ciri khas fisioterapi yang dapat dikenali oleh orang lain dan masyarakat.

g. Dalam menjalankan segala kegiatan fisioterapi berpegang teguh pada kode etik profesi.

h. Mempunyai kemampuan untuk menetapkan keputusan, kemampuan menilai hasil kerja bertanggung jawab dan bertanggung gugat.

\section{Mahasiswa yang Belajar Praktek Pengalaman Klinis}

Departemen Kesehatan Republik Indonesia (2001:1) menyebutkan bahwa klinik/klinis, adalah bagian dari rumah sakit atau lembaga kesehatan tempat orang berobat dan memperoleh advis medis serta tempat mahasiswa kedokteran dan mahasiswa kesehatan belajar mengadakan pengamatan dan pengkajian terhadap kasus-kasus penyakit yang diderita para pasien. Dengan demikian pengalaman klinik merupakan pengalaman belajar praktik mahasiswa yang diperoleh dari lahan praktek, dengan atau tanpa bimbingan para instruktur mahasiswa, yang diharapkan akan dapat memperoleh pengetahuan, ketrampilan, nilai dan sikap dalam kaitannya dengan tujuan pendidikan kesehatan yang diharapkan.

\section{METODE PENELITIAN}

Penelitian menggunakan metode kualitatif dengan pendekatan etnometodologi yaitu studi tentang bagaimana individu menciptakan dan memahami kehidupannya sehari-hari atau etnometodologi berusaha memahami bagaimana orang-orang melihat, menerangkan dan menguraikan keteraturan dunia tempat mereka hidup. Penelitian dilakukan di Instalasi Fisioterapi Rawat Jalan Rumah Sakit Ortopedi Prof. Dr. R. Soeharso, Surakarta yang 
beralamat di Jalan Ahmad Yani Pabelan Kartasura pada kurun waktu bulan Mei 2006 sampai dengan bulan Pebruari 2007. Data bersumber dari kegiatan praktek mahasiswa per bulan, responden/informan dan dokumen. Pengambilan data dilakukan dengan cara pengambilan data laporan status klinis, mengelompokkan dan mengatur jenis laporan status klinis dan penggunaan dokumen.

Peneliti sehari-hari bekerja sebagai fisioterapis serta sekaligus menjadi instruktur klinik bagi mahasiswa yang belajar pengalaman klinis di Rumah Sakit Ortopedi. Populasi penelitian adalah seluruh mahasiswa program Diploma-III Fisioterapi sejumlah 36 orang yang berasal dari Poltekes Surakarta dan Universitas Kristen Indonesia Jakarta dan program Diploma-IV Fisioterapi sejumlah 46 orang yang berasal dari Universitas Indonusa Esa Unggul Jakarta, Poltekes Surakarta dan Universitas Muhammadiyah Surakarta. Peneliti mengambil mahasiswa praktek yang diampu oleh peneliti sebagai instruktur klinis sesuai dengan tugas yang diberikan oleh koordinator praktikan fisioterapi dari sejumlah mahasiswa praktek untuk mewakili kelompok yang ada. Sampel berjumlah 12 orang yang terdiri dari 6 orang mahasiswa D-III dan 6 orang mahasiswa D-IV.

Cara menganalisis melalui metode etnometodologi indukif dalam hal ini mengikuti pendapat Sutopo (2006:106) yang menyatakan bahwa analisis induktif sama sekali tidak dimaksudkan untuk membuktikan prediksi atau hipotesis penelitian, tetapi kesimpulan yang ditarik sampai teori yang dikembangkan, dibentuk dari hasil temuan yang dikumpulkan di lahan praktek. Adapun indikator untuk 3 variabel untuk mahasiswa D-III adalah:

1. Ketrampilan Komunikasi Interpersonal, yang meliputi indikator anamnesis umum, anamnesis khusus, anamnese system, anamnesis tambahan dan famili anamnesis.

2. Penguasaan Teori-Praktek Fisioterapi, yang meliputi indikator pemeriksaan administrasi, inspeksi, pemeriksaan fisik, pemeriksaan gerakan dasar, pemeriksaan psikis, pemeriksaan kemampuan fungsional dan lingkungan aktifitas dan pemeriksaan spesifik.

3. Kompetensi Profesi Fisioterapis Mahasiswa, yang meliputi indikator problematik pasien, diagnosa fisioterapi, program/rencana fisioterapi, tindakan/intervensi fisioterapi, rencana evaluasi, prognosis, pelaksanaan fisioterapi, evaluasi dan hasil terapi akhir.

Sedangkan indikator untuk 3 variabel untuk mahasiswa D-IV adalah:

1. Ketrampilan Komunikasi Interpersonal, yang meliputi indikator anamnesis identitas umum penderita, anamnesis khusus riwayat penyakit, anamnese system/keluhan subyektif, dan famili anamnesis.

2. Penguasaan Teori-Praktek Fisioterapi, yang meliputi indikator pemeriksaan administrasi, inspeksi, pemeriksaan fisik tanda-tanda vital, pemeriksaan gerakan dasar, pemeriksaan psikis, pemeriksaan kemampuan fungsional dan lingkungan aktifitas dan pemeriksaan spesifik.

3. Kompetensi Profesi Fisioterapis Mahasiswa, yang meliputi indikator problematik pasien, diagnosa fisioterapi, program/rencana fisioterapi, tindakan/intervensi fisioterapi, rencana evaluasi, prognosis, pelaksanaan fisioterapi, evaluasi dan hasil terapi akhir. 
Adapun kisi-kisi penilaian indikator adalah:

$0=$ Amat Kurang (mahasiswa tidak menulis),

$1=$ Kurang (mahasiswa menulis salah)

2 = Cukup (mahasiswa menulis sebagian benar)

3 = Cukup Baik (mahasiswa menulis cukup banyak yang benar)

4 = Baik (mahasiswa menulis semua benar)

5 = Amat Baik (mahasiswa menulis benar dan luas pemahamannya)

Menurut Moleong (2004:171), untuk menetapkan keabsahan data (trustworthiness) diperlukan teknik pemeriksaan. Pelaksanaan teknik pemeriksaan didasarkan atas sejumlah kriteria tertentu yang digunakan dan menurut Moleong ada empat kriteria, yaitu : derajat kepercayaan (credibility), keteralihan (transferability), kebergantungan (dependability) dan kepastian (confirmability).

\section{HASIL DAN PEMBAHASAN}

\section{Ketrampilan Komunikasi Interpersonal}

Tabel 1: Hasil Penilaian Ketrampilan Komunikasi Interpersonal Mahasiswa Program D-3

\begin{tabular}{|c|l|c|c|c|c|c|c|}
\hline \multicolumn{2}{|c|}{ Subyek } & \multicolumn{7}{|c|}{ Mahasiswa Program D-3 Fisioterapi } \\
\cline { 2 - 8 } Sumber Data & A & B & C & D & E & F \\
\hline 1 & Anamnesis Umum & 4 & 4 & 4 & 4 & 4 & 4 \\
\hline 2 & Anamnesis Khusus & 2 & 3 & 2 & 3 & 3 & 4 \\
\hline 3 & Anamnese Sistem & 1 & 2 & 0 & 2 & 5 & 4 \\
\hline 4 & AnamnesisTambahan & 0 & 4 & 0 & 4 & 4 & 4 \\
\hline 5 & Famili Anamnesis & 2 & 1 & 0 & 2 & 4 & 4 \\
\hline
\end{tabular}

Tabel 2: Hasil Penilaian Ketrampilan Komunikasi Interpersonal Mahasiswa Program D-4

\begin{tabular}{|c|l|c|c|c|c|c|c|}
\hline \multicolumn{2}{|c|}{ Subyek } & \multicolumn{7}{c|}{ Mahasiswa Program D-4 Fisioterapi } \\
\cline { 3 - 9 } \multicolumn{2}{|c|}{ Sumber Data } & A & B & C & D & E & F \\
\hline 1 & Anamnesis Umum & 4 & 4 & 4 & 4 & 4 & 4 \\
\hline 2 & Anamnesis Khusus & 3 & 3 & 2 & 3 & 5 & 5 \\
\hline 3 & Anamnese Sistem & 0 & 0 & 0 & 0 & 0 & 0 \\
\hline 4 & AnamnesisTambahan & 0 & 0 & 3 & 4 & 4 & 5 \\
\hline 5 & Famili Anamnesis & 1 & 1 & 1 & 4 & 0 & 3 \\
\hline
\end{tabular}

Secara garis besar, ketrampilan komunikasi interpersonal mahasiswa program D-3 Fisioterapi bervariasi dari kurang, cukup, cukup-baik dan baik, namun lebih dominan pada kategori cukup-baik dan baik. Untuk mahasiswa program D-4 Fisioterapi ketrampilan komunikasi interpersonal juga bervariasi dari kurang, cukup, cukup-baik dan baik, namun lebih dominan pada kategori kurang, cukup dan cukup baik. 
Secara umum, ketrampilan komunikasi interpersonal mahasiwa program D-3 Fisioterapi lebih baik dibandingkan dengan ketrampilan komunikasi interpersonal mahasiswa program D-4 Fisioterapi. Hal ini dapat disebabkan karena mahasiswa program D-3 Fisioterapi sepenuhnya mengacu pada petunjuk teknis pengisian laporan status klinis yang telah disediakan serta melakukan cara berkomunkasi interpersonal yang baik. Sedangkan mahasiswa program D-4 Fisioterapi kurang telitia atau mengabaikan penyusunan prosedur penulisan laporan kasus atau tidak mampu mengembangkan petunjuk teknis yang telah dipelajari, serta kurang mempelajari cara berkomunikasi interpersonal yang baik.

\section{Penguasaan Teori-Praktik Fisioterapi}

Tabel 3: Hasil Penilaian Penguasaan Teori-Praktek Fisioterapi Mahasiswa Program D-3

\begin{tabular}{|c|l|c|c|c|c|c|c|}
\hline \multicolumn{2}{|c|}{ Subyek } & \multicolumn{6}{|c|}{ Mahasiswa Program D-3 Fisioterapi } \\
\cline { 2 - 8 } Sumber Data & A & B & C & D & E & F \\
\hline 1 & Pemeriksaan administrasi & 2 & 4 & 4 & 4 & 4 & 4 \\
\hline 2 & Inspeksi & 2 & 3 & 3 & 4 & 5 & 5 \\
\hline 3 & Pemeriksaan fisik & 4 & 3 & 3 & 3 & 3 & 4 \\
\hline 4 & Pemeriksaan gerakan dasar & 2 & 3 & 3 & 4 & 3 & 3 \\
\hline 5 & Pemeriksaan psikis & 4 & 3 & 3 & 4 & 4 & 3 \\
\hline 6 & $\begin{array}{l}\text { Pemeriksaan kemampuan } \\
\text { fungsional dan lingkungan } \\
\text { aktifitas }\end{array}$ & 1 & 2 & 2 & 4 & 3 & 5 \\
\hline 7 & Pemeriksaan spesifik & 0 & 3 & 4 & 2 & 3 & 4 \\
\hline
\end{tabular}

Tabel 4: Hasil Penilaian Penguasaan Teori-Praktik Fisioterapi Mahasiswa Program D-4

\begin{tabular}{|l|l|c|c|c|c|c|c|}
\hline \multicolumn{2}{|c|}{ Subyek } & \multicolumn{5}{|c|}{ Mahasiswa Program D-4 Fisioterapi } \\
\cline { 2 - 9 } Sumber Data & A & B & C & D & E & F \\
\hline 1 & Pemeriksaan administrasi & 2 & 3 & 2 & 3 & 4 & 5 \\
\hline 2 & Inspeksi & 2 & 4 & 2 & 4 & 5 & 5 \\
\hline 3 & Pemeriksaan fisik & 4 & 4 & 4 & 4 & 4 & 4 \\
\hline 4 & Pemeriksaan gerakan dasar & 1 & 3 & 3 & 3 & 4 & 5 \\
\hline 5 & Pemeriksaan psikis & 0 & 4 & 2 & 0 & 0 & 5 \\
\hline 6 & $\begin{array}{l}\text { Pemeriksaan kemampuan fungsional } \\
\text { dan lingkungan aktifitas }\end{array}$ & 3 & 3 & 3 & 3 & 4 & 5 \\
\hline 7 & Pemeriksaan spesifik & 3 & 3 & 3 & 5 & 4 & 5 \\
\hline
\end{tabular}

Secara garis besar, penguasaan teori-praktek fisioterapi mahasiswa program D-3 Fisioterapi bervariasi dari cukup, cukup baik, dan baik, namun lebih dominan pada kategori baik. Sedangkan untuk mahasiswa program D-4 Fisioterapi juga bervariasi dari cukup, cukup-baik, baik dan amat baik, tetapi lebih dominan pada katergori baik. 
Penguasaan teori praktik fisioterapi bagi mahasiswa program D-3 Fisioterapi dan D-4 Fisioterapi sama-sama baiknya, artinya mereka dapat memahami teori dan dapat mengaplikasikannya ke dalam praktek pemeriksaan fisioterapi kepada pasien.

\section{Kompetensi Profesi Fisioterapi}

Tabel 5: Hasil Penilaian Kompetensi Profesi Fisioterapi Mahasiswa Program D-3

\begin{tabular}{|c|l|c|c|c|c|c|c|}
\hline \multirow{2}{*}{ Subyek } & \multicolumn{6}{|c|}{ Mahasiswa Program D-3 Fisioterapi } \\
\cline { 2 - 9 } Sumber Data & A & B & C & D & E & F \\
\hline 1 & Problematik pasien & 2 & 2 & 4 & 3 & 4 & 4 \\
\hline 2 & Diagnosa fisioterapi & 2 & 2 & 2 & 3 & 4 & 4 \\
\hline 3 & Program / rencana fisioterapi & 2 & 3 & 2 & 3 & 4 & 4 \\
\hline 4 & Tindakan / intervensi fisioterapi & 2 & 3 & 4 & 4 & 3 & 5 \\
\hline 5 & Edukasi & 2 & 3 & 4 & 3 & 3 & 5 \\
\hline 6 & Rencana evaluasi & 2 & 4 & 2 & 4 & 4 & 4 \\
\hline 7 & Pronosis & 3 & 3 & 4 & 4 & 4 & 4 \\
\hline 8 & Pelaksanaan fisioterapi & 2 & 2 & 4 & 4 & 4 & 4 \\
\hline 9 & Evaluasi & 3 & 4 & 4 & 4 & 3 & 5 \\
\hline 10 & Hasil terapi akhir & 3 & 4 & 3 & 4 & 4 & 4 \\
\hline
\end{tabular}

Tabel 6: Hasil Penilaian Kompetensi Profesi Fisioterapi Mahasiswa Program D-4

\begin{tabular}{|c|l|c|c|c|c|c|c|}
\hline \multirow{2}{*}{ Subyek } & \multicolumn{5}{|c|}{ Mahasiswa Program D-4 Fisioterapi } \\
\cline { 2 - 9 } Sumber Data & A & B & C & D & E & F \\
\hline 1 & Probematik pasien & 4 & 4 & 4 & 4 & 4 & 4 \\
\hline 2 & Diagnosa fisioterapi & 4 & 4 & 4 & 4 & 5 & 5 \\
\hline 3 & Program / rencana fisioterapi & 4 & 4 & 4 & 4 & 5 & 5 \\
\hline 4 & Tindakan / intervensi fisioterapi & 0 & 3 & 4 & 3 & 5 & 3 \\
\hline 5 & Edukasi & 3 & 0 & 0 & 0 & 4 & 4 \\
\hline 6 & Rencana evaluasi & 0 & 0 & 0 & 4 & 4 & 4 \\
\hline 7 & Pronosis & 0 & 0 & 0 & 4 & 4 & 4 \\
\hline 8 & Pelaksanaan fisioterapi & 2 & 3 & 3 & 3 & 5 & 0 \\
\hline 9 & Evaluasi & 2 & 3 & 4 & 3 & 5 & 5 \\
\hline 10 & Hasil terapi akhir & 0 & 0 & 0 & 4 & 5 & 5 \\
\hline
\end{tabular}

Secara garis besar, kompetensi profesi fisioterapi mahasiswa program D-3 Fisioterapi bervariasi dari cukup, cukup-baik, baik, amat-baik, namun dominan pada kategori cukupbaik. Sedangkan untuk mahasiswa program D-4 Fisioterapi juga bervariasi dari cukup, cukup-baik, dan baik, namun dominan pada kategori baik. Kompetensi profesi fisioterapi mahasiswa program D-3 Fisioterapi berbeda dengan kompetensi profesi fisioterapi mahasiswa program D-4 Fisioterapi. Hal ini dapat dipahami karena mahasiswa program D- 
4 Fisioterapi memiliki kepercayaan diri yang lebih besar dalam mengambil keputusan dan pemecahan masalah dibandingkan dengan mahasiswa program D-3 Fisioterapi.

\section{KESIMPULAN}

Kesimpulan dari pembahasan ini adalah: Pertama, secara umum, ketrampilan komunikasi interpersonal mahasiwa program D-3 Fisioterapi lebih baik dibandingkan dengan ketrampilan komunikasi interpersonal mahasiswa program D-4 Fisioterapi. Kedua, penguasaan teori praktek fisioterapi bagi mahasiswa program D-3 Fisioterapi dan D-4 Fisioterapi sama-sama baiknya. Ketiga, kompetensi profesi fisioterapi mahasiswa program D-3 Fisioterapi berbeda dengan kompetensi profesi fisioterapi mahasiswa program D-4 Fisioterapi.

\section{Implikasi}

Terdapat keterkaitan/implikasi (implication) antara hasil dengan apa yang dilakukan para mahasiswa selama belajar klinis dan apa yang harus dilakukan oleh pembimbing praktik klinis untuk para mahasiswa.

Pertama, kepada para mahasiswa yang belajar praktek klinis fisioterapi di Rumah Sakit Ortopedi, ketrampilan komunikasi interpersonal, penguasaan teori praktek fisioterapi dan kompetensi profesi fisioterapi, merupakan satu rangkaian (sequence) pengetahuan, tindakan, nilai dan sikap yang harus dilakukan untuk menangani pasien (jangan mengabaikan salah satupun) demi keberhasilan terapi. Ketiganya menunjukkan sejauh mana kemampuan mahasiswa selama belajar praktek.

Kedua, kepada para pembimbing praktek klinis fisioterapi di Rumah Sakit Ortopedi, mohon jangan lupa memberikan penjelasan khusus tentang ketrampilan komunikasi interpersonal, penguasaan teori praktek fisioterapi, kompetensi profesi fisioterapi kepada para mahasiswa yang belajar praktek klinis fisioterapi, bahwa ketiganya merupakan satu rangkaian (sequence) pengetahuan, tindakan nilai dan sikap yang harus dilakukan mahasiswa untuk menangani pasien (jangan mengabaikan salah satupun) demi keberhasilan terapi.

Ketiga, lebih banyak meningkatkan kemampuan/kemahiran dalam mendiagnosis, merencanakan terapi dan melakukan tindakan terapi serta untuk mengevaluasinya bagi mahasiswa yang masuk dalam kategori cukup dan cukup-baik, untuk memperoleh hasil yang optimal dalam menangani kasus yang dialami oleh penderita.

\section{REFERENSI}

Berne Eric. 1972. Games People Play. USA : Grouve Press. Inc New York.

Corner John And Hausthon Jeremy. 1993. Communication Studies.London, New York,

Sidney, Auckland : Edward Arnold a member of the Hodder Heddline PLC.

Dalyono. 1997. Psikologi Pendidikan. Jakarta : PT Rineka Cipta.

Dawis, Fruehling, Oldam. 1989. Psychology Behaviour, Motivation and Work Adjustment.

Eden Prairie : Paradigm Publishing International.

Dedi Supriyadi. 2004. Membangun Bangsa Melalui Pendidikan. Bandung : PT. Remaja Rosdakarya. 
Dep.Kes. RI. 2001. Pedoman Pengelolaan Lahan Praktek. Jakarta : Pusat Pendidikan Tenaga Kesehatan. . 2002. Registrasi Fisioterapi Indonesia dan Pelatihan Asuhan Fisioterapi.

Jakarta : Badan Pelayan Kesehatan dan Ikatan Fisioterapi Indonesia.

Driscoll Marcy P. 1994. Psychology of Learning for Introduction. Boston, London, Toronto, Sydney, Tokyo, Singapore : Allyn \& Bacon. A Division of Paramont Publishing. Inc.

Fatah Syukur. 2005. Teknologi Pendidikan. Semarang : Walisongo Pres dengan RaSAIL. Griffin EM. 2000. Communication Theory. USA : The McGraw Hill Companies Inc. Hartono. 2003. Bagaimana Menulis Tesis. Malang : Universitas Muhammadiyah.

Harris Thomas.A. 1983. Saya Oke, Kaти Oke. (Terjemahan). Jakarta : Yayasan Cipta Loka Caraka.

Hogesschool Van Amsterdam. 1991. Pemeriksaan Fisioterapi Pegangan untuk Dosen. Amsterdam : Onderwijs Programma Indonesiche Fysiotherapie.

Holmberg, Börje. 1992. Theory and Practic of Distance Education. London and New York : Routledge.

Ikatan Fisioterapi Indonesia. 2001. Kode Etik Profesi Fisioterapi Indonesia. Jakarta : Rumah Sakit Siaga Raya.

Jalaludin Rakhmat. 2001. Psikologi Komunikasi. Bandung : PT Remaja Rosdakarya. Kuncaraningrat. 1977. Metode-Metode Penelitian Masyarakat. Jakarta : PT Gramedia. Latipun. 2001. Psikologi Konseling. Malang : Universitas Muhammadiyah.

Liliveri. Alo 2001. Gatra-Gatra Komunikasi Antar Budaya. Yogyakarta : Pustaka Pelayan Offset. 1997. Komunikasi Antar Pribadi .Bandung : PT. Aditya Bakti.

Littlejohn. 1992. Theories of Human Communication. New Mexico : Wadsworth Publishing Company.

Magee David J. 1987. Orthopedic Physical Assessment. Philadelphia, London, Toronto, Mexico City : W. B. Saunders Company.

Miles. .Mattthew B, Huberman. A. Michael. 1992. "Analisis Data Kualitatif” (Terjemahan.). Jakarta : UI-Press.

Moffat, et all The American Psysical Therapy Association 1999. Book of Body Maintenance and Repair. New York : Henry Holt and Company.

Moleong. 2004. Metode Penelitian Kualitatif. Bandung : PT Remaja Rosdakarya. Muhibin Syah. 2001. Psikologi Pendidikan dengan Pendekatan Baru. Bandung : PT Remaja Rosdakarya.

Mulyasa. 2004. Kurikulum Berbasis Kompetensi. Bandung : PT Remaja Rosdakarya. Niven Neil. 2002. Psikologi Kesehatan. Jakarta : Penerbit Buku Kedokteran EGC.

Oemar Hamalik. 2004. Pendidikan Guru Berdasarkan Pendekatan Kompetensi. Jakarta : PT Bumi Aksara.

RSO. 2001. 50 Tahun Pelayanan Ortopedi dan Rehabilitasi. Surakarta : Rumah Sakit Ortopedi Prof. Dr. R. Soeharso.

Schement, Jorge Reina. 2002. Encyclopedia of Communication and Information. London, Munich : Macmillan Reference USA, an imprint of Gale Group.

Sells, Barbara B, Richey C. 1994. Pembelajaran Difinisi dan Kawasannya ("Edisi Terjemahan oleh Dewi S. Prawirodilogo, Raphael Rahardjo, Yusufhadi Miarso”). Jakarta : Universitas Negeri. 1994. Intructional Technology Definition and Domain of the Field. Vermon Avc., N.W. Suit. Washington DC : Association Education Communication and Technology. 
Sardiman. 2004. Interaksi dan Motivasi Belajar-Mengajar. Jakarta : PT Raja Grafindo Persada.

Sevilla Consuelo G,at all. 1993. Pengantar Metode Penelitian ("Terjemahan Alimudin Tuwu”). Jakarta : Universitas Indonesia (UI-Press).

Soenarwan. 2001. Pendekatan System dalam Pendidikan. Surakarta : Sebelas Maret University Press.

Sikun Pribadi. 1984. Psikologi Pendidikan. Jakarta : CV Radjawali.

Soeharso. 1982. Pengantar Ilmu Bedah Ortopedi. Yogyakarta : Yayasan Essensia Medika. Sugiyono. 2005. Memahami Penelitian Kualitatif. Bandung : CV.Alfabeta.

Suharsimi Arikunto. 2001. Dasar-Dasar Evaluasi Pendidikan. Jakarta : PT Bumi Aksara.

Supratiknyo. 1995. Komunikasi antar Pribadi Tinjauan Psikologi. Yogyakarta : Kanisius. Sutopo. 2006. Metodologi Penelitian Kualitatif. Surakarta : Universitas Sebelas Maret. Thomson, Skinner, Fiercy. 1991. Tidy's Physiotherapy. Oxford, London, Guildford, Boston, Munich, New Delhi, Singapore, Sydney, Tokyo, Toronto, Wellington : Butter-Worth-Heinemann.

Tilaar. 2004. Membenahi Pendidikan Nasional. Jakarta : PT Rineka Cipta.

Winkel. 1987. Psikologi Pendidikan dan Evaluasi Belajar. Jakarta : PT Gramedia.

Winter Richard. 1996. Learning from Experience : Principle and Practice in the Action Research. New York, Philadelphia: The Palmer Press.

WCPT.1995. Deklarasi Prinsip dan Pernyataan Sikap ("Terjemahan Ikatan Fisioterapi Indonesia”). Washington DC : General Assembly WCPT.

Wolf de, Mens 1994. Pemeriksaan Alat Penggerak Tubuh. Houten/zaventem : Bohn Stafleu Van Loghum. 